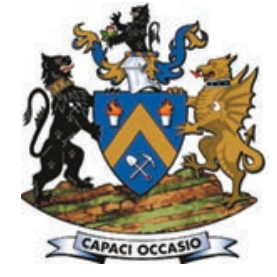

Affiliation:

1Department of Mining

Engineering, Faculty of

Engineering, Karadeniz Technical

University, Trabzon, Turkey.

2Department of Metallurgical and

Materials Engineering, Faculty of

Engineering, Karadeniz Technical

University, Trabzon, Turkey.

${ }_{3}^{3}$ Materials Science and

Production Technologies Applied

Research Center (ATARC),

Istanbul Technical University,

Istanbul, Turkey.

\section{Correspondence to:}

T. Türk

Email:

tugbayilmaz@ktu.edu.tr

Dates:

Received: 28 May 2019

Revised: 19 Mar. 2020

Accepted: 6 Apr. 2020

Published: May 2020

How to cite:

Türk, T., Alp, I., Sezer, R., and

Arslan, C.

Removal of arsenic from water using copper slag.

The Southern African Insitute of

Mining and Metallurgy

DOI ID:

http://dx.doi.org/10.17159/2411-

9717/766/2020

ORCiD ID:

T. Türk

https://orcid.org/0000-0001-

5993-2548

I. Alp

https://orcid.org/0000-0002-

6032-3528

R. Sezer

https://orcid.org/0000-0001-

9655-2114

C. Arslan

https://orcid.org/0000-0002-

0034-7560

\title{
Removal of arsenic from water using copper slag
}

\author{
T. Türk1, í. Alp' ${ }^{1}$ R. Sezer2,3, and C. Arslan ${ }^{3}$
}

\section{Synopsis}

The potential use of copper slag (CS) as an adsorbent for removing arsenic contaminant from water was examined. The influence of solution $\mathrm{pH}$, initial arsenate (As(V)) and arsenite (As(III)) concentrations, and adsorbent dosage was investigated by batch experiments to elucidate the adsorption mechanism of arsenate onto CS. The adsorption kinetics indicated that the second-order kinetic model best described the adsorption process. The adsorption data was analysed by the isotherm models, and was well fitted by the Langmuir model. The maximum removal of As(V) and As(III) achieved was $98.76 \%$ and $88.09 \%$, respectively at an adsorbent dose of $10 \mathrm{~g} / \mathrm{L}$ with an initial $\mathrm{As}(\mathrm{V})$ and $\mathrm{As}(\mathrm{III})$ concentration of $300 \mu \mathrm{g} / \mathrm{L}$ This study showed that copper slag is a suitable adsorbent for removal of arsenic from water, with a capacity to reduce arsenic levels to $<10 \mu \mathrm{g} / \mathrm{L}$, below the limit set for water by World Health Organization.

\section{Keywords}

waste management, copper slag, adsorption, arsenic removal.

\section{Introduction}

Arsenic is one of the most harmful and toxic elements found in nature. Arsenic is introduced into water through both natural and anthropogenic sources (Hossain, 2006). There have been reports of arsenic poisoning in Argentina, Bangladesh, India, Nepal, Taiwan, the USA, and Turkey (Jean, Bundschuh, and Bhattacharya, 2010). Prolonged exposure to arsenic can lead to serious health problems such as cancers of the liver, kidney, skin, and stomach (Meng, Bang, and Korfiatis, 2000). This suggests an urgent need for efficient and low-cost arsenic removal techniques. The World Health Organization (WHO) has set the drinking water standard at $10 \mathrm{ppb}(0.01 \mathrm{mg} / \mathrm{L})$ (WHO, 1993).

Surface and groundwaters contaminated with pollutants can be treated by various methods such as coagulation, precipitation, membrane processes, and adsorption (Mohan, and Pittman, 2007). Many kinds of adsorbents such as iron oxide-loaded slag (Lakshmipathiraj et al., 2006), activated alumina (Thirunavukkarasu, 2002), anionic clays (Türk and Alp, 2012), nano-magnetite (Türk, Alp, and Deveci, 2010) and Fe-hydrotalcite (Türk and Alp, 2010) have been developed to remove arsenic. Previous studies reported that iron-based minerals were useful in the removal of arsenic from water. Although many adsorbents have been developed, few of them are implemented in small settlements to remove pollutants from groundwater (Makris, Sarkar, and Datta, 2006). For these reasons, low-cost waste materials for application in rural areas at a small scale are in high demand. An example of such processes is the use of a waste by-product from the flotation of a copper slag (CS) as a low-cost sorbent. CS is obtained during the smelting and refining of copper and contains copper, zinc, cobalt, and nickel (Gorai, Jana, and Premchand, 2003). During smelting, a copper-rich matte phase (sulphides) and slag phase (oxide-rich) are formed. The slag phase consists predominantly of $\mathrm{FeO}, \mathrm{Fe}_{2} \mathrm{O}_{3}$, and $\mathrm{SiO}_{2}$, with small amounts of $\mathrm{Al}_{2} \mathrm{O}_{3}, \mathrm{CaO}$ and $\mathrm{MgO}$, and $\mathrm{Cu}, \mathrm{Co}$, and $\mathrm{Ni}$ (as metal) (Davenport et al., 2002).

The annual CS waste production capacity in the Black Sea Copper Works is approximately $150000 \mathrm{t}$ (Alp et al., 2009). As a result, about 1.5-2.0 Mt of CS waste has been disposed of. Improper disposal can result in the toxic metal ions leaching into the groundwater, with ensuing serious environmental problems (Davenport et al., 2002). Due to environmental restrictions and lack of storage space, various options for the treatment of waste materials have been investigated. CS wastes are used in various applications to recycle waste products and to prevent pollution (Alp et al., 2009). The use of CS as an iron source in the production of Portland cement has been reported. Adsorption is an effective and inexpensive method of waste remediation, if adsorbent can be obtained cheaply and in large amounts (Zhang et al., 2004). Arsenic is strongly adsorbed on Fe oxides and hydroxides (Türk and Alp, 


\section{Removal of arsenic from water using copper slag}

2012) which are abundant in CS. However, a literature review discovered no reports on the use of CS for arsenic removal from water. In this research, the arsenic removal characteristics of CS were investigated.

\section{Experimental}

\section{Materials}

CS obtained from the Black Sea Copper Works (Samsun, Turkey) was used as adsorbent. The chemical composition of the slag was determined using inductively coupled plasma mass spectrometry (ICP-MS, ACME Analytical Laboratories). The major components in the sample were $\mathrm{Fe}_{2} \mathrm{O}_{3}(59.08 \%)$ and $\mathrm{SiO}_{2}$ (30.60\%). The Brunauer-Emmett-Teller method was used to determine the surface area (for CS; $4.81 \mathrm{~m}^{2} / \mathrm{g}$ ). X-ray diffraction (XRD) patterns of CS were obtained using a RIGAKU D/Max-IIIC diffractometer. The operating conditions were $35 \mathrm{kV}-15 \mathrm{~mA}$, and the sample was scanned between $2^{\circ}$ and $60^{\circ}$. A pinch of CS sample was poured onto adhesive carbon tape, and then its surface was covered with a very thin $(5-10 \mu \mathrm{m})$ gold layer by the physical vapour deposition (PVD) technique. The results of the X-ray analysis and a scanning electron microscopy (SEM, JEOL JSM 5600) secondary ion image of CS are shown in Figure 1. In the example, fayalite $\left(\mathrm{Fe}_{2} \mathrm{SiO}_{4}\right)$, magnetite $\left(\mathrm{Fe}_{3} \mathrm{O}_{4}\right)$, quartz $\left(\mathrm{SiO}_{2}\right)$, and cristobalite $\left(\mathrm{SiO}_{2}\right)$ are present.

\section{Adsorption tests}

The arsenic stock solution was prepared using sodium arsenate $\left(\mathrm{Na}_{2} \mathrm{HAsO}_{4} \cdot 7 \mathrm{H}_{2} \mathrm{O}\right.$, from Sigma) and sodium arsenite $\left(\mathrm{NaAsO}_{2}\right.$, Sigma) in pure water. Adsorption tests were carried out in flasks immersed in a temperature-controlled water bath at room temperature (nearly $25^{\circ} \mathrm{C}$ ), and agitated at $130 \mathrm{r} / \mathrm{min}$ with a mechanical shaker. The effects of the initial arsenic concentration $(10,50,100,300$, and $500 \mu \mathrm{g} / \mathrm{L})$, contact time $(1,3,5,7$, and 24 hours), adsorbent dosage $(1,5,10,20$, and $50 \mathrm{~g} / \mathrm{L})$, and $\mathrm{pH}$ $(3,5,7$, and 9$)$ on the adsorption of arsenic were studied. The isothermal and kinetic studies were conducted using $50 \mathrm{~mL}$ of solution (a series of $100 \mathrm{~mL}$ flasks) of As(V) and As(III) (10, 50, 100,300 , and $500 \mu \mathrm{g} / \mathrm{L}$ ) at an adsorbent dosage of $10 \mathrm{~g} / \mathrm{L}$. The collected samples were then centrifuged for 10 minutes at $4000 \mathrm{r} / \mathrm{min}$. Arsenic concentrations were determined by inductively coupled plasma optical emission spectrophotometry (ICP-OES).
The point of zero charge $\left(\mathrm{pH}_{\mathrm{pzc}}\right)$ of CS was found to be 7 ; this was determined by equilibrating CS with $0.1 \mathrm{M} \mathrm{NaCl}$ solutions at different pH values (3-12). Türk, Alp, and Deveci (2010) give details of the procedure.

\section{Results and discussion}

\section{Adsorption of arsenic}

In adsorption processes, $\mathrm{pH}$ is an important parameter. It affects the speciation of metal in aqueous solution and the surface charge of adsorbent (Zhang, and Hideaki, 2005). Figure 2 shows the effect of $\mathrm{pH}$ on the adsorption of As(V) and As(III) onto CS. It can be seen that the arsenic adsorbed is independent of $\mathrm{pH}$ value. After 5 hours of adsorption, the residual $\mathrm{As}(\mathrm{V})$ in solution was determined to be $6.2-2.0 \mu \mathrm{g} / \mathrm{L}$, and As(III) $55.2-40.0 \mu \mathrm{g} / \mathrm{L}$ at $\mathrm{pH} 3-9$. The $\mathrm{pH}_{\mathrm{pzc}}$ value of the CS sample was determined to be $\mathrm{pH} 7$, and at $\mathrm{pH}$ values greater than $\mathrm{pH}_{\mathrm{pzc}}$, the $\mathrm{CS}$ surface is negatively-charged. Although the adsorbent surface and sorbate types were negatively charged, adsorption was not decreased at $\mathrm{pH}$ values above $\mathrm{pH}_{\mathrm{pzc}}$. This may be due to the buffer effect. In a low-pH medium, the $\mathrm{pH}$ of the bulk solution increases in the presence of CS. At high pH values, acid dissociation of CS reduces the $\mathrm{pH}$ of the solution (Tian, and Shen, 2009). As a result, a pH value of 9.0 was selected, and all experiments in the study were performed at $\mathrm{pH} 9$.

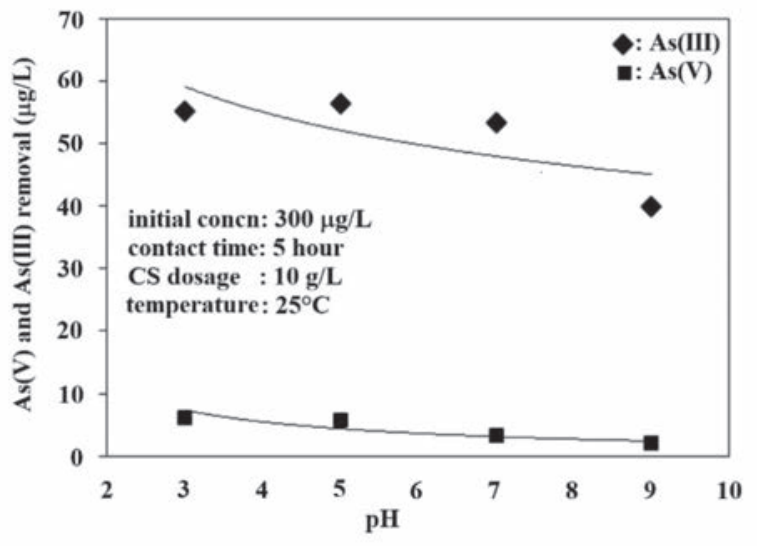

Figure 2-Effect of $\mathrm{pH}$ on arsenic removal

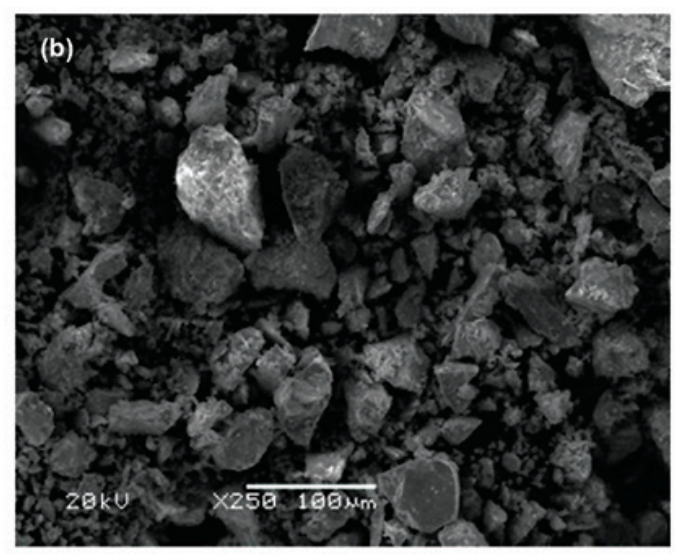

Figure 1-(a) X-ray diffraction spectrum of CS and (b) SEM image 


\section{Removal of arsenic from water using copper slag}

Figure 3 shows the effect of CS dosage. Arsenic removal efficiency increased with increasing CS. At the end of 5 hours at a CS dosage of $1 \mathrm{~g} / \mathrm{L}$, the concentrations of $\mathrm{As}(\mathrm{V})$ and $\mathrm{As}(\mathrm{III})$ in solution were $104.3 \mu \mathrm{g} / \mathrm{L}$ and $142.3 \mu \mathrm{g} / \mathrm{L}$ respectively, compared to 6.31 and $19.3 \mu \mathrm{g} / \mathrm{L}$ at $10 \mathrm{~g} / \mathrm{L} \mathrm{CS}$. All further experiments in the study were performed at a dosage of $10 \mathrm{~g} / \mathrm{L} \mathrm{CS}$.

\section{Kinetic modelling}

The removal of $\mathrm{As}(\mathrm{V})$ and $\mathrm{As}(\mathrm{III})$ versus time is illustrated in Figure 4. CS removed more than $81 \%$ of the arsenic within the first hour, and the removal efficiency increased gradually to $99 \%$ within 3 hours. The adsorption capacity for arsenic was approximated to $30 \mu \mathrm{g} / \mathrm{g}$ at sorption equilibrium. In these experiments, only $0.5 \mathrm{~g}$ of CS was placed in a flask containing up to $100 \mathrm{~mL}$ of arsenate solution at a concentration of $300 \mu \mathrm{g} / \mathrm{L}$. The adsorption kinetics depend strongly on the characteristics of the adsorbent material and adsorbate species, which also influence the adsorption mechanism (Bektaş, Akman, and Kara, 2004). Pseudo-first-order and pseudo-second-order models were used to determine experimental kinetic data models and to understand the mechanism of the adsorption process. The pseudo-first-order equation (Ho, and McKay, 1998) is

$$
\ln \left(q_{e}-q_{t}\right)=\ln q_{e}-k_{1} t
$$

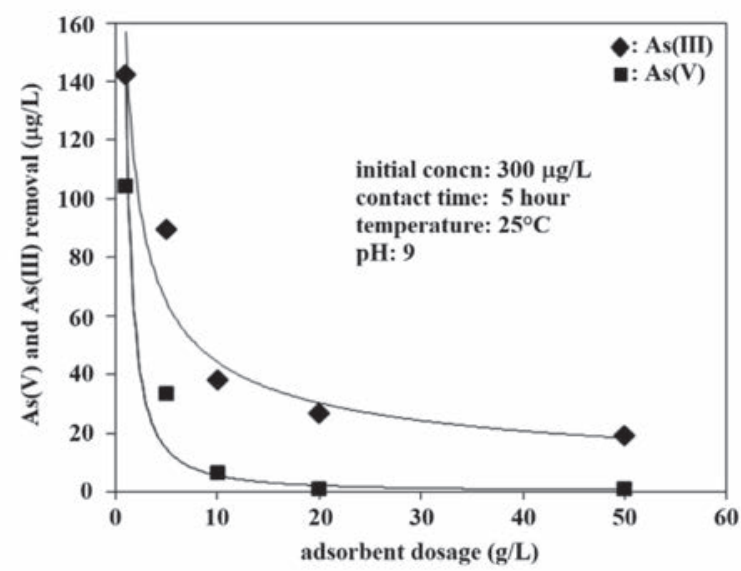

Figure 3-Effect of adsorbent dosage

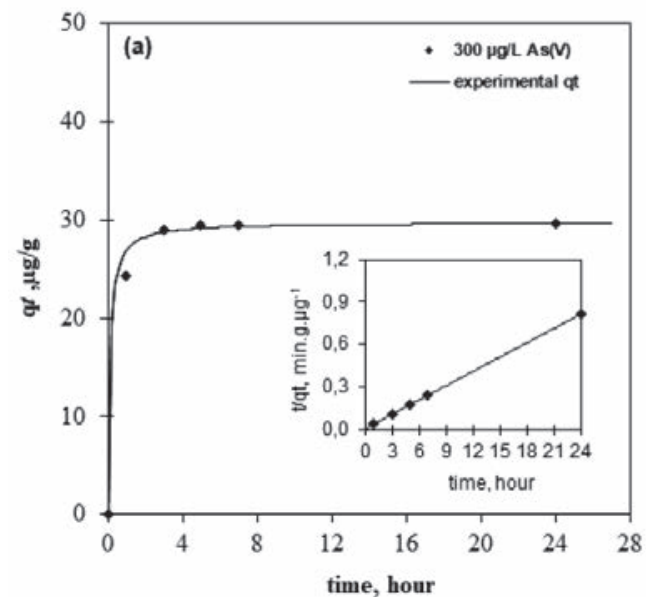

$$
\frac{t}{q_{t}}=\frac{1}{k_{2} q_{e}^{2}}+\frac{t}{q_{e}}
$$

where $q_{e}$ is the adsorption capacity $(\mu \mathrm{g} / \mathrm{g})$ at equilibrium, $q$, the adsorption capacity $(\mu \mathrm{g} / \mathrm{g})$ at time $t, k_{1}$ the pseudo-first-order rate constant $\left(\mathrm{min}^{-1}\right)$, and $k_{2}$ is the pseudo-second-order rate constant $\left(\mathrm{g} \mathrm{mg}^{-1} \mathrm{~s}^{-1}\right)$.

The first-order rate constant $k_{1}$ and equilibrium adsorption density $q_{e}$ (Equation [1]) at initial concentrations of $\mathrm{As}(\mathrm{V})$ and As(III) were calculated using the slope and intercept of plots of $\log \left(q_{e}--q_{t}\right)$ versus $t$. The coefficients of determinations $\mathrm{R}^{2}$ were found to be 0.947 and 0.854 , respectively.

Pseudo-second-order adsorption parameters $q_{e}$ and $k_{2}$ in Equation [2] were determined by plotting $t / q_{t}$ versus $t$ (Figure $4 \mathrm{a}, 4 \mathrm{~b})$. The coefficient of determination $\left(\mathrm{R}^{2}\right)$ of the pseudosecond-order kinetic model is 0.999 , higher than the coefficient of determination of the pseudo-first-order model. A high coefficient of determination suggests that the pseudo-second-order kinetic model better represents the adsorption kinetics and that $\mathrm{As}(\mathrm{V})$ and As(III) ions are adsorbed on the CS surface through chemical interaction (Bulut, Özacar, and Şengil, 2008). The calculated $q_{e}$ values also agreed well with the experimental data.

\section{Adsorption equilibrium}

The equilibrium adsorption of arsenic as a function of the arsenic concentration was investigated to determine the adsorption capacity of CS. The Langmuir, Freundlich, Dubinin-Radushkevich (D-R), and Temkin models were tested. The adsorption isotherms are shown in Figure 5.

\section{Freundlich isotherm}

The Freundlich isotherm is an empirical equation based on a heterogeneous surface and multilayered sorption. The higher the $K_{f}$ value, the higher the adsorbate affinity (Mohamad, Amir, and Sudabeh, 2013).

The linear form of the equation (Veli, and Akyüz, 2007) is

$$
\ln q_{e}=\ln K_{f}+\frac{1}{n} \ln C_{e}
$$

where $q_{e}$ is the amount of adsorbate at equilibrium ( $\left.\mu \mathrm{g} / \mathrm{g}\right), C_{e}$ is the equilibrium concentration of adsorbate $(\mu \mathrm{g} / \mathrm{L}), n$ is adsorption intensity, and $K_{f}$ is the Freundlich constant. The linear plot of $\ln$

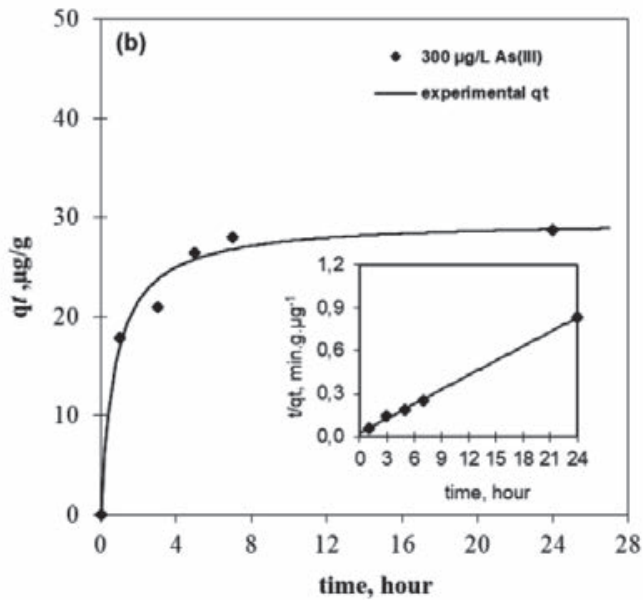

Figure 4-Effect of time on (a) As(V) and (b) As(III) absorption. Initial conc. $300 \mu \mathrm{g} / \mathrm{L}$; CS dosage $10 \mathrm{~g} / \mathrm{L}$; $25^{\circ} \mathrm{C}$. The smaller inset graphs show the pseudo-second-order plots 


\section{Removal of arsenic from water using copper slag}

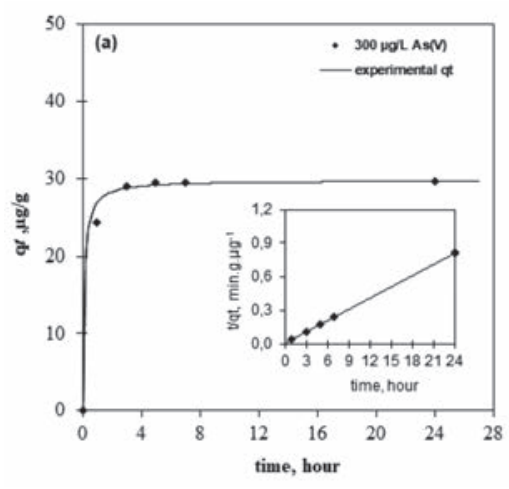

Figure 5-Equilibrium isotherms for adsorption

$q_{e}$ and $\ln C_{e}$ gives a slope of $1 / n$ and intercept of $\ln K_{f}$ In theory, values of $n$ from 1 to 10 indicate that the adsorbate is adsorbed appropriately on the adsorbent (Konicki et al., 2012). In this study, $n=1.73$. The Freundlich adsorption isotherm model is shown in Figures 6 and 7. The coefficient of determination of this model is lower than those for the other three isotherms (Table I).

\section{Langmuir isotherm}

The Langmuir isotherm is the most widely used isotherm for removal of contaminants from solutions (Crini et al., 2009; Özacar and Şengil, 2005). The Langmuir isotherm suggests that adsorption occurs in a single layer on the surface of a homogeneous adsorbent (Foo and Hameed, 2010).

The linear form of the conventional Langmuir model (Kundu and Gupta, 2007) is

$$
\frac{1}{q_{e}}=\frac{1}{b Q C_{e}}+\frac{1}{Q}
$$

where $C_{e}$ is the equilibrium concentration $(\mu \mathrm{g} / \mathrm{L}), b$ is the adsorption constant $(\mathrm{L} / \mu \mathrm{g}), q_{e}$ is the amount of arsenic at equilibrium $(\mu \mathrm{g} / \mathrm{g})$, and $Q$ is the adsorption capacity $(\mu \mathrm{g} / \mathrm{g})$.

The Langmuir constants and coefficient of determination $\left(\mathrm{R}^{2}\right)$ values were obtained from the slope and intercept of the linear plot of $1 / q_{e}$ versus $1 / C_{e}$ (Figures 6 and 7 , Table I). The Langmuir model was best fitted to experimental data with high $\mathrm{R}^{2}$ values.

The Langmuir isotherm can be explained by the $R_{L}$ parameter (Kundu, and Gupta, 2007), which is defined by Equation [5]

$$
R_{L}=\frac{1}{1+b C_{0}}
$$

where $C_{o}(\mu \mathrm{g} / \mathrm{L})$ is the initial concentration and $b(\mathrm{~L} / \mu \mathrm{g})$ is the Langmuir constant. $R_{L}$ values may indicate unfavourable $\left(R_{L}\right.$ $>1)$, linear $\left(R_{L}=1\right)$, favourable $\left(0<R_{L}<1\right)$, or irreversible $\left(R_{L}=0\right)$ adsorption (Tekin, 2006). The values of RL for our experiments were found to be $<0.04$, indicating that the adsorption by CS is favourable.

The Langmuir isotherm is well adapted to the experimental data. It is an indication of single layer adsorption of arsenic on CS (Bulut, Özacar, and Şengil, 2008). The Langmuir isotherm model is widely used in explaining chemical adsorption (Dubinin, 1960). The isotherm study was conducted using different arsenic concentrations $(50-300 \mu \mathrm{g} / \mathrm{L})$ at $25^{\circ} \mathrm{C}, \mathrm{pH} 9,0.5 \mathrm{~g}$ dosage of CS, and absorption time 5 hours. For CS, the maximum adsorption capacities in arsenate and arsenite solution were found to be 109 and $84.8 \mu \mathrm{g} / \mathrm{g}$ respectively, using the Langmuir isotherm. The maximum adsorption capacities of some iron-based adsorbent materials are compared with this value. Thirunavukkarasu, Viraraghavan, and Subramanian (2003) studied the adsorption of

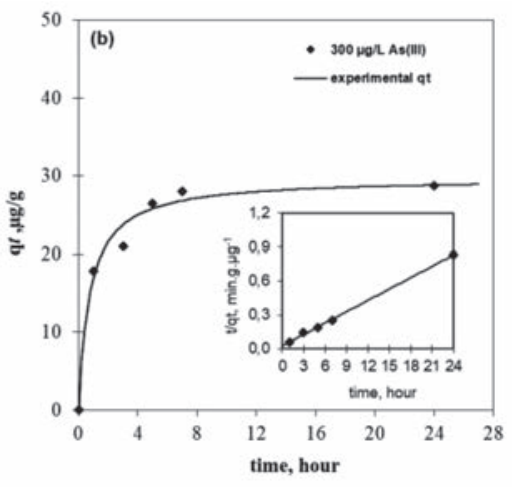

As(V). on iron oxide-coated sand. They found that the adsorption capacity was $45 \mu \mathrm{g} / \mathrm{g}$. Guo, Stüben, and Berner (2007) studied $\mathrm{As}(\mathrm{V})$ removal using haematite. The adsorption capacity of haematite was found to be $204 \mu \mathrm{g} / \mathrm{g}$ (As(V) from a $1000 \mu \mathrm{gL}$ solution at an adsorbent dosage of $10 \mathrm{~g} / \mathrm{L}$ ). Türk and Alp (2010) reported adsorption capacities of $80 \mu \mathrm{g} / \mathrm{g}$ for $\mathrm{As}$ (III) on Fehydrotalcite.

\section{Dubinin-Radushkevich (D-R) isotherm}

The Dubinin-Radushkevich (D-R) isotherm model is used to distinguish the physical and chemical adsorption of arsenic ions on CS (Dubinin, 1960). This model is written as (Kundu, and Gupta, 2007)

$$
q_{e}=Q_{D} \exp \left(-B_{D} \varepsilon^{2}\right)
$$

and linearized as

$$
\ln q_{e}=\ln Q_{D}-B_{D} \varepsilon^{2}
$$

where $Q_{D}$ is the maximum capacity (mol/g), $B_{D}$ is the D-R constant $\left(\mathrm{mol}^{2} / \mathrm{kJ}^{2}\right)$, and $\varepsilon$ is the Polanyi potential and is equal to $\varepsilon=R T \ln \left(1+\frac{1}{C_{e}}\right)$.

Figures 6 and 7 show the plot of $\ln q_{e}$ against $\varepsilon^{2}$. The coefficient of determination $\mathrm{R}^{2}=0.9166 . B_{D}$ was found to be $0.34 \mathrm{~mol}^{2} / \mathrm{J}^{2}$, and $Q_{D}$ was $35.63 \mathrm{~mol} / \mathrm{g}$.

The free energy of adsorption $(E)$ was determined using the relationship $E=\frac{1}{\sqrt{2 B D}}$ (Kundu,and Gupta,2007). The value of $E$ is significant when ascertaining the type of adsorption. If the $E$ value is less than $8 \mathrm{~kJ} / \mathrm{mol}$, adsorption is physical, and if it is $8-16 \mathrm{~kJ} / \mathrm{mol}$, adsorption is chemical (Islam, Mishra, and Patel, 2011). In this investigation the value of $E$ was found to be $0.84 \mathrm{~kJ} / \mathrm{mol}$ (Table I), thus in this case, the adsorption is physical. Similar results have been reported for the adsorption of arsenic by iron-oxide-coated granular activated charcoal (Ananta, Saumen, and Vijay, 2015).

\section{Temkin isotherm}

The Temkin isotherm is based on adsorbate-adsorbent interactions. This model ignores deficient and extremely high concentrations, and the free energy of adsorption is a function of the surface coating. The Temkin isotherm is given as (Mall et al., 2005):

$$
\begin{aligned}
& q_{e}=\frac{R T}{b} \ln \left(A C_{e}\right) \\
& \frac{R T}{b}=B
\end{aligned}
$$

The linear form of the Temkin isotherm is 


\section{Removal of arsenic from water using copper slag}

$$
q_{e}=B \ln A+B \ln C_{e}
$$

where $A$ is the equilibrium binding constant $(\mathrm{L} / \mu \mathrm{g}), b$ is the Temkin constant $(\mathrm{J} / \mathrm{mol}), R$ is the gas constant $(8.314 \mathrm{~J} / \mathrm{mol} \mathrm{K})$, and $\mathrm{T}$ is the absolute temperature $(\mathrm{K})$ equivalent. The adsorption data was analysed and the values of the Temkin constants A and $B$ and coefficient of determination established; these are listed in Table I, and the theoretical plot of this isotherm is shown in Figures 6 and 7. According to the coefficients of determination $\left(\mathrm{R}^{2}\right)$, the order of suitability of the models was Langmuir, Freundlich, D-R, and Temkin (Figures 6, 7 and Table I). Thus, the Langmuir model is the most suitable for describing single-layer adsorption of arsenic on the CS surface. The adsorption capacities $(Q)$ for $\mathrm{As}(\mathrm{V})$ and $\mathrm{As}(\mathrm{III})$ in the Langmuir model were 109.460 and $84.83 \mu \mathrm{g} / \mathrm{g}$, respectively. As a result, the isothermic order is Langmuir $>$ Temkin $>$ Freundlich, $>$ D-R isotherm.

\section{Conclusion}

In this study, the removal of $\mathrm{As}(\mathrm{V})$ and $\mathrm{As}(\mathrm{III})$ from aqueous solution by copper slag (CS) was demonstrated. The pH effect
Table I

Calculated Isotherm parameters $\left(10 \mathrm{~g} / \mathrm{L} \mathrm{CS}, 25^{\circ} \mathrm{C}\right)$

\begin{tabular}{|l|c|c|c|c|}
\hline \multirow{2}{*}{ Parameter } & \multicolumn{2}{|c|}{ As(V) } & \multicolumn{2}{c|}{ As(III) } \\
\cline { 2 - 5 } & Value & $\mathbf{R}^{2}$ & Value & $\mathbf{R}^{2}$ \\
\hline $\begin{array}{l}\text { Langmuir } \\
Q(\mu \mathrm{g} / \mathrm{g}) \\
b \quad 0.083\end{array}$ & 109.29 & 0.991 & 84.83 & 0.981 \\
\hline Freundlich & & & 0.030 & \\
$K_{f}$ & 8.88 & 0.895 & 1.37 & 0.917 \\
$n$ & 1.73 & & 1.00 & \\
\hline D-R & & & & \\
$Q_{D}$ & 35.63 & 0.916 & 26.80 & 0.816 \\
$B_{D}$ & 0.34 & & 0.23 & \\
\hline Temkin & & & & \\
$A$ & 2.64 & 0.982 & 0.09 & 0.950 \\
$B$ & 11.4 & & 15.5 & \\
\hline
\end{tabular}
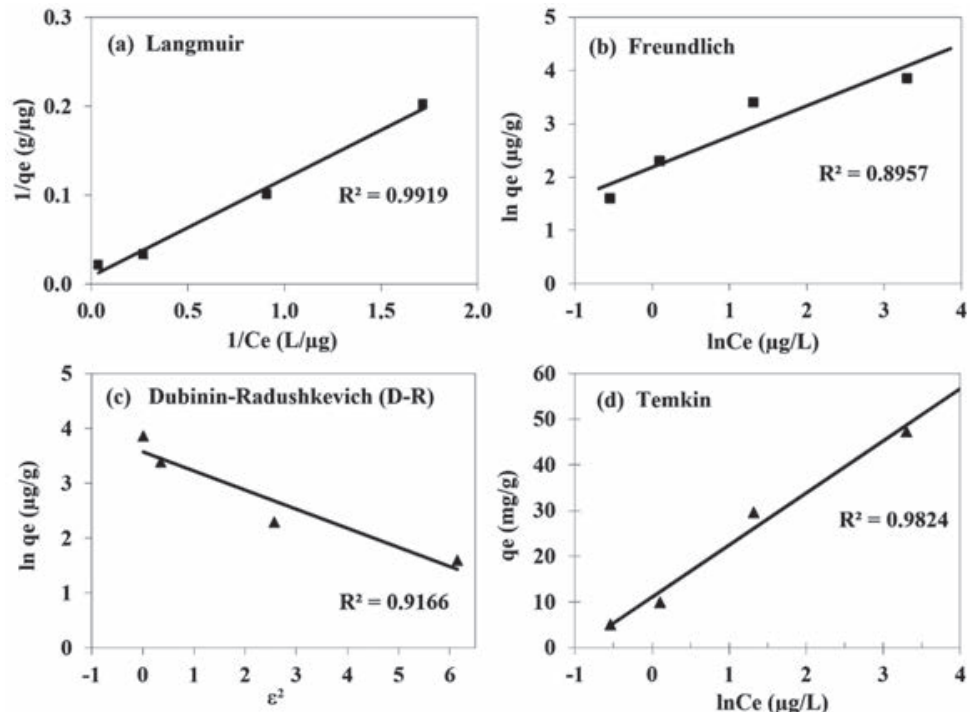

Figure 6-Adsorption isotherm plots for $\mathrm{As}(\mathrm{V})$
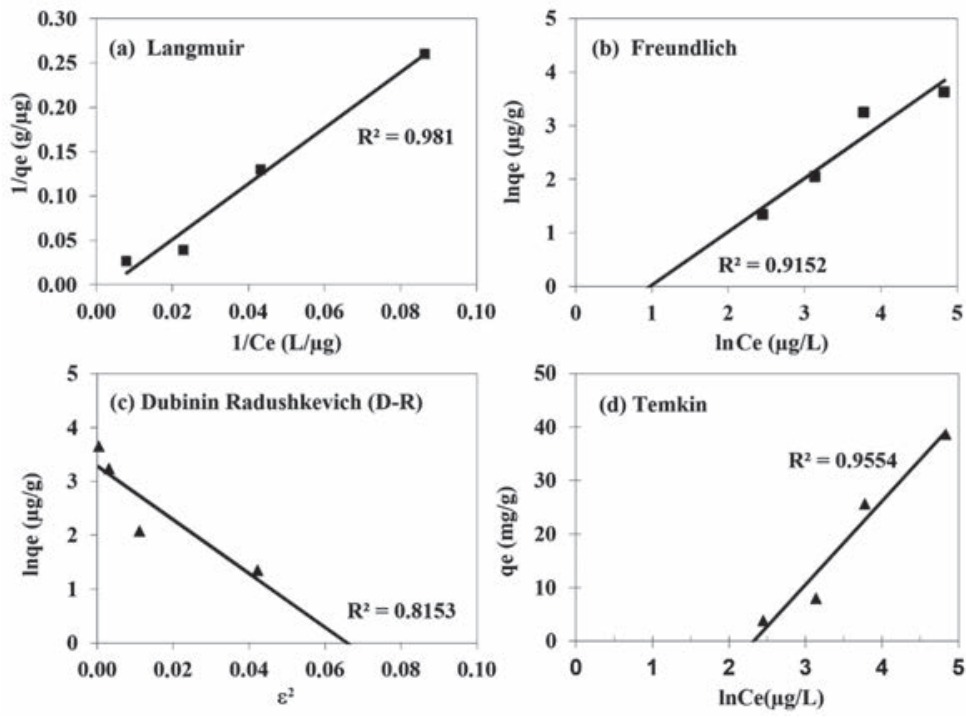

Figure 7-Adsorption isotherm plots for As(III) 


\section{Removal of arsenic from water using copper slag}

study showed that the amount of arsenic adsorbed by CS was independent of initial $\mathrm{pH}$ value. Kinetic studies showed that the rate of adsorption accords with the pseudo-second-order kinetic model and that arsenic ions are adsorbed on the CS surface through chemical interaction. The adsorption data was analysed by Langmuir, Freundlich, Dubinin-Radushkevich (D-R) and Temkin isotherm models and the data was well fitted using the Langmuir isotherm model. The Langmuir isotherm model is widely used in explaining chemical adsorption. The maximum adsorption capacities of the sorbent in As(V) and As(III) solution were found to be 109.29 and $84.83 \mu \mathrm{g} / \mathrm{g}$, respectively. The RL value $(<0.04)$ showed that CS is favourable for the removal of arsenic from aqueous solutions. Under optimal conditions (adsorbent dosage $10 \mathrm{~g} / \mathrm{L}$, solution $\mathrm{pH} 9$, temperature $25^{\circ} \mathrm{C}$, and arsenic concentration of $300 \mu \mathrm{g} / \mathrm{L}$ the adsorbent was able to remove $98.76 \%$ of the arsenate and $85.43 \%$ of the arsenite. CS can be used as a practical, easy to use, and inexpensive adsorbent for arsenate and arsenite removal from water.

\section{Acknowledgement}

The authors thank the Black Sea Copper Works (Samsun, Turkey) for providing the samples CS.

\section{References}

Alp, İ., Deveci, H., Yazici, E.Y., Türk, T., and Sungun, H. 2009. Potential use of pyrite cinders as raw material in cement production: Results of industrial scale trial operations. Journal of Hazardous. Materials, vol. 166. pp. 144-149. do1:10.1016/j.jhazmat.2008.10.129

Ananta, S., Saumen, B., and VIIAY, V. 2015. Adsorption isotherm, thermodynamic and kinetic study of arsenic (III) on iron oxide coated granular activated charcoal. International Research Journal of Environmental Sciences, vol. 4. pp. 64-77.

Bektaş, N., Akman A.B., and Kara, S. 2004. Kinetic and equilibrium studies in removing lead lons from aqueous solutions by natural sepiolite. Journal of Hazardous. Materials, vol. 12, pp. 115-122. doi:10.1016/j. jhazmat.2004.04.015

Bulut, E., ÖZACAR, M., and ŞENGIL, I.A. Equilibrium and kinetic data and process design for adsorption of congo red onto bentonite. Journal of Hazardous. Materials, vol. 154. pp. 613-622. do1:10.1016/j.jhazmat.2007.10.071

Crinl, G., Peindy, H.N., Gimbert, F., and RoberT, C. 2007. Removal of C.I. Basic Green 4, (Malachite Green) from aqueous solutions by adsorption using cyclodextrinbased adsorbent: kinetic and equilibrium studies, Separation and Purification Technology, vol. 53. pp. 97-110. do1:10.1016/j.seppur.2006.06.018

Davenport, W.G., King, M., Schlesinger, M., and Biswas, A.K. Extractive Metallurgy of Copper. 4th edn. Pergamon Press, Oxford.

Dubinis, M.M. 1960. The potential theory of adsorption of gases and vapors for adsorbents with energetically nonuniform surface. Chemical Reviews, vol. 60. pp. 235-266. do1: 10.1021/cr60204a006

Foo, K.Y. and Hameed, B.H. 2010. Insights into the modeling of adsorption isotherm systems. Chemical Engineering Journal, vol. 156. pp. 2-10. do1:10.1016/j. cej.2009.09.013

Gorai, B., Jana, R.K., and Premchand. 2003. Characteristics and utilization of copper slag - A review. Resource Conservation and Recycling, vol. 39. pp. 299-313. dol:10.1016/S0921-3449(02)00171-4

Guo, H., StüBen, D., and Berner, Z. 2007. Removal of arsenic from aqueous solution by natural siderite and hematite. Applied Geochemistry, vol. 22. pp. 1039-1051. dol:10.1016/j.apgeochem.2007.01.004

Ho, Y.S. and McKAY, G. 1998. Kinetic model for lead(II) sorption onto peat. Adsorption Science and Technology, vol. 16. pp. 243-255. do1:10.1177/026361749801600401

Hossain, M.F. 2006. Arsenic contamination in Bangladesh - An overview. Agriculture, Ecosystems \& Environment, vol. 113. pp. 1-16. dol:10.1016/j. agee.2005.08.034

IsLAm, M., Mishra, P.C., and Patel, R. 2011. Fluoride adsorption from aqueous solution by a hybrid thorium phosphate composite. Chemical Engineering Journal, vol. 166. pp. 978-985. do1:10.1016/j.cej.2010.11.087

Jean, J.S., Bundschuh, J., and BhatTacharya, P. 2010. Arsenic in Geosphere and Human Diseases. Balkema, CRC Press.

Konicki, W., PeŁech, I., Mijowska, E., and JasińsKa, I. Adsorption of anionic dye Direct Red 23 onto magnetic multi-walled carbon nanotubes-Fe3C nanocomposite: Kinetics, equilibrium and thermodynamics. Chemical Engineering Journal, vol. 210. pp. 87-95. dol:10.1016/j.cej.2012.08.025

Kundu, S. and GuPTA, A.K. 2007. Adsorption characteristics of As (III) from aqueous solution on iron oxide coated cement (IOCC). Journal of Hazardous. Materials, vol. 142. pp. 97-104. dol:10.1016/j.jhazmat.2006.07.059

Lakshmipathira, P., Narasimhan, B.R.V., Prabhakar, S., and Bhaskar Raju, S.G. 2006. Adsorption of arsenate on synthetic goethite from aqueous solutions. Journal of Hazardous. Materials, vol. 136. pp. 281-287. dol:10.1016/j. jhazmat.2005.12.015

MAKRIS, K.C., SARKAR, D., and DATTA, R. 2006. Evaluating a drinking-water waste by-product as a novel sorbent for arsenic. Chemosphere, vol. 64. pp. 730-741. doi:10.1016/j.chemosphere.2005.11.054

Mall, I.D., SRivastava, V.C., Agarwall, N.K., and Mishra, I.M. 2005. Removal of Congo Red from aqueous solution by bagasse fly ash and activated carbon. Kinetic study and equilibrium isotherm analysis, Chemosphere, vol. 61. pp. 492-501. do1:10.1016/j.chemosphere.2005.03.065

Meng, X.G., Bang, S., and Korfiatis, G.P. 2000. Effects of silicate, sulfate, and carbonate on arsenic removal by ferric chloride. ii, vol. 34. pp. 1255-1261. DOI:10.1016/S0043-1354(99)00272-9

Mohamad, A.B., Amir, H.M., and Sudaber, P. 2013. Thermodynamic analysis of reactive Red 198 removal from synthetic wastewater by using multiwall carbon nanotubes. Health Scope, vol. 2. pp. 149-155. doi: 10.17795/ jhealthscope- 13438

Mohan, D. and Pittman, C.U. 2007. Arsenic removal from water/wastewater using adsorbents - A critical review. Journal of Hazardous. Materials, vol. 142. pp. 1-53. do1: 10.1016/j.jhazmat.2007.01.006

Özacar, M. and Şengil, I.A. 2005. Adsorption of metal complex dyes from aqueous solutions by pine sawdust. Bioresource Technology, vol. 96. pp. 791-795. dol:10.1016/j.biortech.2004.07.011

Tekin, N., Kadinci, E., Demirbaş, Ö., AlKan, M., and Kara, A. 2006. Adsorption of polyvinylimidazole onto kaolinite. Journal of Colloids and Interface Science, vol. 296. pp. 472-479. do1:10.1016/j.jcis.2005.09.049

ThiRUNAVUKKARASU, O.S. 2001. Removal of arsenic from drinking water, PhD thesis, Regina University, Regina, Saskatchewan.

ThirunavukKarasu, O.S., Viraraghavan, T., and Subramanian, K.S. 2003. Arsenic removal from drinking water by iron-oxide coated sand. Water, Air, \& Soil Pollution, vol. 142. pp. 95-111. doi:10.1023/A:1022073721853

TiAn, C.S. and SHEN, Y.R. 2009. Structure and charging of hydrophobic material/wate interfaces studied by phase-sensitive sum-frequency vibrational spectroscopy. Proceedings of the National Academy of Sciences, vol. 106. pp. 15148-15153. do1:10.1073/pnas.0901480106

TüRK, T. and Alp, I. 2010. Adsorption of As(III) from water using Mg-Fehydrotalcite (FeHT). Ekoloji, vol. 74. pp. 77-88 [in Turkish]. doi: 10.5053/ ekoloji.2010.7411

TüRK, T. And Alp, I. 2012. Adsorption of arsenic from borated water using Mg-Fehydrotalcite (FeHT). Ekoloji, vol. 84. pp. 98-106. [in Turkish]. doi: 10.5053/ ekoloji.2012.8411

TÜRK, T., Alp, I., and Deveci, H. 2010. Adsorptive removal of arsenite from water using nanomagnetite. Desalination and Water. Treatment, vol. 24. pp. 302-307. do1:10.5004/dwt.2010.1404

Vel, S. and AKYüz, B. 2007. Adsorption of copper and zinc from aqueous solutions by using natural clay. Journal of Hazardous. Materials, vol. 149. pp. 226-233. do1:10.1016/j.jhazmat.2007.04.109

World Health Organization. 1993. WHO guidelines for drinking water quality. Geneva. 41 pp.

ZHANG, F. and HideAкI, I. 2005. Iron oxide-loaded slag for arsenic removal from aqueous system. Chemosphere, vol. 60. pp. 319-325. do1:j. chemosphere.2004.12.019

Zhang, W., Singh, P., Paling, E., and Delides, S. 2004. Arsenic removal from contamined water by natural iron ores. Minerals Engineering, vol. 17 pp. 517-524. do1:j.mineng.2003.11.020 